\title{
ПРАКТИЧНІ ПРИЙОМИ ВИКОРИСТАННЯ ТЕХНОЛОГІЇ «МАЙНДМЕППІНГ» В НАВЧАННІ АНГЛІЙСЬКОЇ МОВИ СТУДЕНТІВ ІНЖЕНЕРНИХ СПЕЦІАЛЬНОСТЕЙ
}

\author{
Моргунова Н. С. \\ кандидат психологічних наук, \\ дочент кафедри мовної підготовки \\ Харківський начіональний автомобільно-дорожній університет \\ вул. Ярослава Мудрого, 25, Харків, Україна \\ orcid.org/0000-0003-3107-1103 \\ morgan.ns777@gmail.com \\ Приходько С. О. \\ кандидат педагогічних наук, \\ старший викладач кафедри іноземних мов \\ Харківський начіональний університет міського господарства імені О. М. Бекетова \\ вул. Наталї Ужвій, б. 62, Харків, Украӥна \\ orcid.org/0000-0001-7277-7618 \\ prikhodkoso92@gmail.com
}

\begin{abstract}
Ключові слова:
mind тар, ментальні карти, інтелектуальні карти, навчальна технологія, навчання іноземної мови, студенти технічних закладів вищзої освіти.
\end{abstract}

У статті висвітлено поняття «майндмеппінг», надано теоретичне обгрунтування доцільності впровадження ментальних карт у навчальний процес ЗВО. Розглянуто наукові підходи вітчизняних та зарубіжних вчених до визначення принципів створення та потенційних можливостей застосування ментальних карт у навчанні. Звертається увага на подібності та відмінності ментальних карт і близьких до них опорно-графічних конспектів В. Шаталова та фреймів М. Мінського. Аргументується ефективність застосування майндмеппінгу саме для студентів інженерних спеціальностей, для яких ближчим $є$ системне, предметне, радіальне мислення. Розглядаються переваги та недоліки використання ментальних карт у навчальному процесі, наголошується на необхідності дотримання інтерактивного характеру взаємодії у процесі використання ментальних карт на занятті. Аналізуються потенціал майндмеппінгу як мотивуючого фактора для вивчення іноземної мови, можливості технології у процесі формування та вдосконалення мовних і мовленнєвих навичок і вмінь, засвоєнні соціокультурної інформації, як засобу організації індивідуальної і групової, аудиторної і самостійної роботи студентів, розвитку творчих й інтелектуальних здібностей студентів. Запропоновано шляхи використання ментальних карт у викладанні англійської мови студентам технічних закладів вищої освіти для формування лексичних, граматичних навичок, розвитку писемного мовлення і аудіювання, складання монологічного висловлювання, де необхідним є вміння генерувати свої ідеї, знаходити причинно-наслідкові зв'язки, найбільш раціональне рішення, робити висновки. Звертається увага на методичні правила, які варто враховувати під час використання ментальних карт на занятті. Робиться висновок, що ментальні карти $є$ продуктивною альтернативою традиційним способам обробки інформації, перетворюють студента на активного творця власних знань, дають змогу викладачеві продуктивно використовувати навчальний час і отримувати високі результати в процесі іншомовної підготовки студентів. 


\title{
PRACTICAL METHODS OF USING MIND MAPPING TECHNOLOGIES IN TEACHING ENGLISH FOR STUDENTS OF ENGINEERING SPECIALTIES
}

\author{
Morhunova N. S. \\ Candidate of Psychological Sciences, \\ Associate Professor at the Language Training Department \\ Kharkiv National Automobile and Highway University \\ orcid.org/0000-0003-3107-1103 \\ morgan.ns777@gmail.com \\ Prykhodko S. O. \\ Candidate of Pedagogical Sciences, \\ Senior Lecturer at the Department of Language Training \\ O. M. Beketov National University of Urban Economy in Kharkiv \\ orcid.org/0000-0001-7277-7618 \\ prikhodkoso92@gmail.com
}

\begin{abstract}
Key words:
mind map, mental maps, smart maps, educational technology, teaching a foreign language, students of technical higher educational institutions.
\end{abstract}

The concept of "mind mapping" is highlighted in the article, theoretical justification for the feasibility of introducing mental maps into the educational process of a university is provided. The scientific approaches of native and foreign scientists to the determination of the principles of creation and potential possibilities of using mental maps in training are considered. Attention is drawn to the similarities and differences between mental maps and close to them graphical abstracts by V. Shatalov and frames by M. Minskyi. The effectiveness of the use of mind mapping is argued specifically for students of engineering specialties, for whom systemic, substantive, radial thinking is closer. The advantages and disadvantages of using mental maps in the educational process are considered, the need to observe the interactive nature of collaboration during the use of mental maps in the lesson is emphasized. The potential of mind mapping as a motivating factor for learning a foreign language, the possibility of technology in the process of forming and improving language and speech skills, the assimilation of sociocultural information as a means of organizing individual and group, classroom and independent work of students, and the development of students' creative and intellectual abilities are analyzed. Ways of using mental maps in teaching English to students of technical higher educational institutions are proposed for the formation of lexical, grammatical skills, the development of written speech and listening, composing a monologic statement, where the ability to generate own ideas is important as well as to find causal relationships, the most rational decision, draw conclusions. Attention is drawn to the methodological rules that should be considered when using mental maps in class. It is concluded that mental maps are a productive alternative to traditional methods of information processing, they turn a student into an active creator of his own knowledge, provide an opportunity for a teacher to use study time productively and get high results in the process of foreign language training of students. 
Постановка проблеми. На сучасному етапі розвитку суспільства помічається зміна інформаційних пріоритетів у професійному і міжособистісному спілкуванні, яка виявляється у тому, що візуалізація стає найважливішим принципом комунікації і репрезентації інформації. Стрімкий розвиток комп'ютерних технологій i цифрових засобів передачі візуальної інформації суттєво впливає також на принципи і методи сприймання навчальної інформації інтегрального типу. Саме необхідність пошуку і методологічно обгрунтованого вибору найбільш ефективних методик їх застосування в навчанні іноземної мови визначає актуальність вибраної проблематики.

Ментальні карти (mind maps, mental maps, інтелект-карти, карти пам'яті, асоціативні карти, схеми мислення тощо) і майндмеппінг (технологія роботи з ментальними картами) нині активно розглядаються в аспекті розвитку креативного мислення учнів і студентів, їхніх особистісних, метапредметних i професійних компетенцій. Використання ментальних карт зумовлене необхідністю врахування когнітивних особливостей сучасного покоління студентів, потребою подання навчального матеріалу у вигляді, найбільш зручному для його сприйняття, засвоєння, запам'ятовування і $€$ результативним у навчальному процесі під час конспектування лекцій, підготовки матеріалу за певною темою, підбитті підсумків вивченого розділу, розв'язання творчих завдань, тренінгів тощо.

Аналіз останніх досліджень і публікацій. Головною особливістю побудови ментальних карт $\epsilon$ використання радіального запису та побудова схематичних малюнків як альтернативи традиційному лінійному запису. Питання створення ментальних карт розглядаються в дослідженнях таких зарубіжних науковців, як Т. Бьюзен, Б. Джонс, М. Ейппер, Х. Мюллер, В. Норт, Д. Снайдер, Б. Твісс, Р. Фостер, Й. Шумпетер та ін. Д. Несбіт і О. Адесопе визначають mind тар як «спосіб зображення процесу загального системного мислення, тип графічної організації інформації, який відрізняється використанням маркірованих вузлів, що позначають поняття, і посилань, що показують взаємозв'язки між поняттями» [4, с. 415]. У центрі ментальної карти розміщується головна тема, від якої відходять різнокольорові гілки ключові поняття. Такий спосіб запису дає змогу необмежено розширювати ментальну карту, удосконалюючи її зміст, ефективність, оригінальність за допомогою кольору, малюнків, символів тощо.

Нині проблеми використання ментальних карт знаходяться й у фокусі уваги вітчизняних педагогів. Дослідженню теоретичних аспектів, сутності, структури і видів ментальних карт присвячені роботи Л. Байсари, А. Гореєвої, І. Кіндрат,
А. Кобисі, Н. Кононец, Н. Оксентюк, І. Погребенник, І. Шахіної, О. Язикова та ін. На актуальності й значущості майндмеппінгу у професійній діяльності педагога наголошують О. Романовський, В. Гриньова, О. Резван [3, с. 186], які зосереджують увагу на взаємній доповнювальній діяльності педагога і студента в процесі створення ментальних карт. Визначаючи візуалізацію як один з освітніх трендів майбутнього, О. Алексєєва, Л. Бутенко $[1$, с. 144] позиціонують інтелект-карти як ефективний засіб візуалізації навчальної інформації, що забезпечує змістовну компресію навчального контенту для представлення значних блоків інформації в компактній формі, що дає змогу «не тільки унаочнювати відповідну інформацію, а й стимулювати активну пізнавальну діяльність студентів, розвивати аналітичні уміння та навички, здатність до моделювання як способу пізнання, асоціативне мислення».

Шляхи розробки і впровадження ментальних карт у процес викладання окремих дисциплін у вищій професійній школі висвітлюються в дослідженнях О. Аксьонова, В. Кравченко (економіка), А. Козлової (інформатика), А. Солодовник (фізика), Т. Колтунович, О. Поліщук (психологія), В. Машкіної (географія), Ю. Мінгальової (науково-дослідна діяльність студентів) та ін. Але, незважаючи на багатоаспектність напрацювань із зазначеної проблеми, відчувається недостатність розробки методів впровадження цієї технології в навчальний процес закладу вищої освіти: досі мало дослідженими й обгрунтованими $є$ практичні шляхи використання майндмеппінгу у викладанні іноземної мови.

Мета статті полягає в розкритті переваг використання ментальних карт і їх практичного значення в навчальному процесі, розгляді принципів створення ефективної ментальної карти, дидактичних особливостей використання технології «майндмеппінг» у навчанні іноземної (англійської) мови студентів технічних закладів вищої освіти.

Виклад основного матеріалу. Основою ментальних карт $\epsilon$ схематизація, кодування інформації, подання іiі у вигляді умовних символів та, за необхідністю, коротких письмових пояснень до них. А. Кобися [2, с. 349] проводить паралелі між ментальними картами та опорно-графічними конспектами, що запропонував ще у 70-і роки XX століття заслужений учитель України В. Шаталов, розглядаючи їх як прототип технології «майндмеппінг». Але зауважимо, що опорні схеми В. Шаталова $є$ скоріше набором схематичних зображень, формул, окремих фраз, які допомагають побудувати внутрішній мнемонічний план навчального матеріалу. Не принижуючи їх позитивну роль у підвищенні ефективності навчаль- 
ного процесу, зазначимо, що їх дидактичні можливості не дають змоги відтворити чисельні та різнорідні логічні зв'язки між елементами навчальної інформації, що суттєво обмежує сферу їх використання в навчанні студентів у 3ВО. Більш близькою до майндмеппінгу нам здається фрейм-технологія американського науковця М. Мінського, який запропонував візуалізувати навчальний матеріал за допомогою його структурування певним чином у комірки, наповнені мінімальним описом суті об'єкта чи ситуації. Сам фрейм є змістовним ядром навчальної інформації, ii структури, що здійснює логіко-смисловий зв' язок у вигляді схеми.

Джерелом технології «майндмеппінг»є уявлення про принципи роботи мозку людини (асоціативне мислення, візуалізація уявних образів, цілісне сприйняття (гештальт) тощо). Виходячи 3 цього, ефективний спосіб структурування інформації для запам'ятовування та подальшого відтворення - це надання вихідному матеріалу структури типу «дерево». Такі структури широко використовуються скрізь, де необхідно коротко i компактно подати великий обсяг інформації. У процесі створення ментальних карт варто уникати використання готових традиційних форм, таблиць і схем, оскільки вони підлаштовують під них розумовий процес, обмежуючи думки спочатку заданими стандартними рамками. Зв'язки, що відображує ментальна карта, можуть бути не тільки логічними, але й асоціативними, а записи - не тільки термінологічними, а й образними, приблизними.

На відміну від фахівців гуманітарного профілю, котрим зазвичай легше оперувати словами, студентам технічного профілю зручніше звертатися до предметного і конкретного світу речей. Також необхідно зазначити, що інженерне мислення існує в ідеалізованій графічній площині, але метою його $є$ не виклик естетичної насолоди, а деталізація і конкретизація попередньої інженерної ідеї. Це системотворче мислення дає змогу бачити проблему повністю і з різних сторін, зв' язки між їі частинами: одночасно систему, надсистему, підсистему, зв'язки між ними і всередині них. Саме тому майндмеппінг $є$ технологією, що здатна сприяти формуванню в студентів технічних університетів інженерного мислення й ефективному засвоєнню ними навчальної інформації.

Безумовно, як й будь-яке явище, ментальні карти мають як плюси, так і мінуси. Недоліками можна назвати те, що ментальна карта за своєю суттю є репрезентацією авторської ідеї, структуризація інформації в ній може бути незрозумілою для сприймання іншим. У цьому випадку вона потребує пояснення, коментування, відповідної презентації. Також обмеженість деревоподібної моноієрахічної структури може призводити до надмірної таксономії у процесі групування чи до втрати важливої інформації. Подолати цю проблему допоможе використання різних кольорів чи додаткових сполучних гілок між ключовими поняттями.

Майндмеппінг як навчальна технологія може використовуватися як викладачем у процесі пояснення матеріалу чи його систематизації, так i студентом для ефективного запам'ятовування, осмислення чи відтворення навчальної інформації за допомогою зручних символів та зображень. У процесі застосування технології майндмеппінгу важливим, на нашу думку, є забезпечення інтерактивного характеру ментальних карт, що використовуються викладачем. Карта, що презентується викладачем відразу в остаточному статичному вигляді, втрачає здатність наочно відображати динаміку, хід мисленнєвого процесу. Тому дуже важливо створювати карту поступово, додавати елементи до заздалегідь заготовлених зображень або малювати іiі в онлайн-режимі на інтерактивній дошці (якщо дозволяють технічні можливості аудиторії), покроково ілюструючи етапи міркувань чи розповіді, розглядаючи кожну гілку, що відходить від змістовного ядра, як окремо, так і у зв'язку з іншими.

Можливості майндмеппінгу як у викладанні, так і у вивченні іноземної мови дуже широкі: його можна використовувати у процесі формування та вдосконалення мовних i мовленнєвих навичок $\mathrm{i}$ вмінь, для засвоєння знань соціокультурної спрямованості тощо. Власний досвід використання майндмеппінгу у викладанні англійської мови студентам інженерних спеціальностей дає змогу позитивно оцінити можливості цієї технології в процесі формування лексичних, граматичних навичок, розвитку писемного мовлення і аудіювання, складання монологічного висловлювання, де необхідним $є$ вміння генерувати свої ідеї, знаходити причинно-наслідкові зв'язки, найбільш раціональне рішення, робити висновки.

У процесі роботи ми використовуємо ментальні карти як для введення i закріплення, так i для контролю лексичного матеріалу за певною темою, пропонуючи студентам представити в карті лексику як складну систему логічних зв'язків, де лексичні одиниці представлені не ізольовано, а у зв'язку з іншими, для засвоєння і систематизації граматичного матеріалу, складання планів переказу текстів і вербальних опор для монологічного висловлювання. Під час підготовки до монологічного висловлювання ми пропонуємо студентам використовувати власноруч створену ментальну карту, яка виступатиме наглядною опорою під час їх виступів, а також стане таким способом візуалізації інформації, що у процесі представлення 
iï аудиторії сприятиме більш ефективному сприйманню і запам'ятовуванню необхідних фактів слухачами. Як приклад пропонуємо таку карту, створену студентом, що підсумовує вивчені теми за змістовим модулем «Мовні моделі професійного спілкування» - «Energy Resources» (рис. 1).

Ілюстрацією завдання для самостійної роботи студентів $\epsilon$ створення лексичних карт за вивченою темою, де метою $є$ розподіл лексики за групами, графічне зображення зв'язків між ними чи, наприклад, ментальні карти для переказу тексту. У цьому випадку ми пропонуємо студентам у центрі карти записати назву чи основну ідею, на гілках - ключові словосполучення чи символи, що логічно розкривають цю думку, а далі за допомогою стрілок та ліній між ними вибудовувати певну логічну послідовність розповіді.

Цікавим, на наш погляд, $є$ досвід використання mind map у груповій роботі, коли ми пропонуємо студентам своєрідне змагання - навчальний batlle. Конкуренція у створенні кращої ментальної карти може мотивуватися додатковими балами чи наданням певних привілей, що може значно покращити кінцевий результат навчання і мотивувати студентів.

Найбільш ефективною $є$ методика спільного створення ментальних карт викладачем і студентами. У такому разі карта може бути започаткована викладачем i розширена сумісно зі студентами безпосередньо на занятті відгалуженнями-підтемами чи ідеями. Завершення карти в процесі заняття допоможе систематизувати навчальну інформацію, а на основі такої карти на наступному занятті можна активізувати вивчене.
Як домашнє завдання можна запропонувати студентам поглибити гілки ментальної карти шляхом вивчення додаткового матеріалу (як окремого відгалуження для кожної підтеми, що надалі будуть поєднані, так і всієї карти для подальшого розгляду результатів роботи кожного студента на наступному занятті).

Підбиваючи підсумки роботи над темою, ми пропонуємо студентам самостійно скласти ментальну карту отриманих знань із виділенням червоних областей (незасвоєного простору), зелених областей (засвоєних понять), синіх (частково зрозумілих). У цьому випадку студенту легше проаналізувати свої пробіли в знаннях, а викладачу побачити реальні результати вивченої теми.

Іноді нам доводилося зіштовхуватися з ситуацією, коли студент, отримавши завдання зробити ментальну карту за певною темою, використовував «кліпове» мислення, зображуючи в графічній формі калейдоскоп розрізнених фактів і фрагментів інформації, що затрималися в його пам'яті після прочитання тексту, прослуховування аудіо або перегляду відеоматеріалу, вивчення теми. Здебільшого смислова релевантність і логічна обгрунтованість цих шматочків інформації і їх послідовності виявляється доволі сумнівною. Намагаючись скорегувати цей продукт, викладач може почути негативну відповідь, оскільки студент відтворив у ній результат свого мисленнєвого процесу. Щоб уникнути такої ситуації викладач має спочатку навчити студентів майндмеппінгу, перш ніж його застосовувати, оскільки уявна простота побудови навіть елементарної ментальної карти є дуже оманливою і потребує сформованих

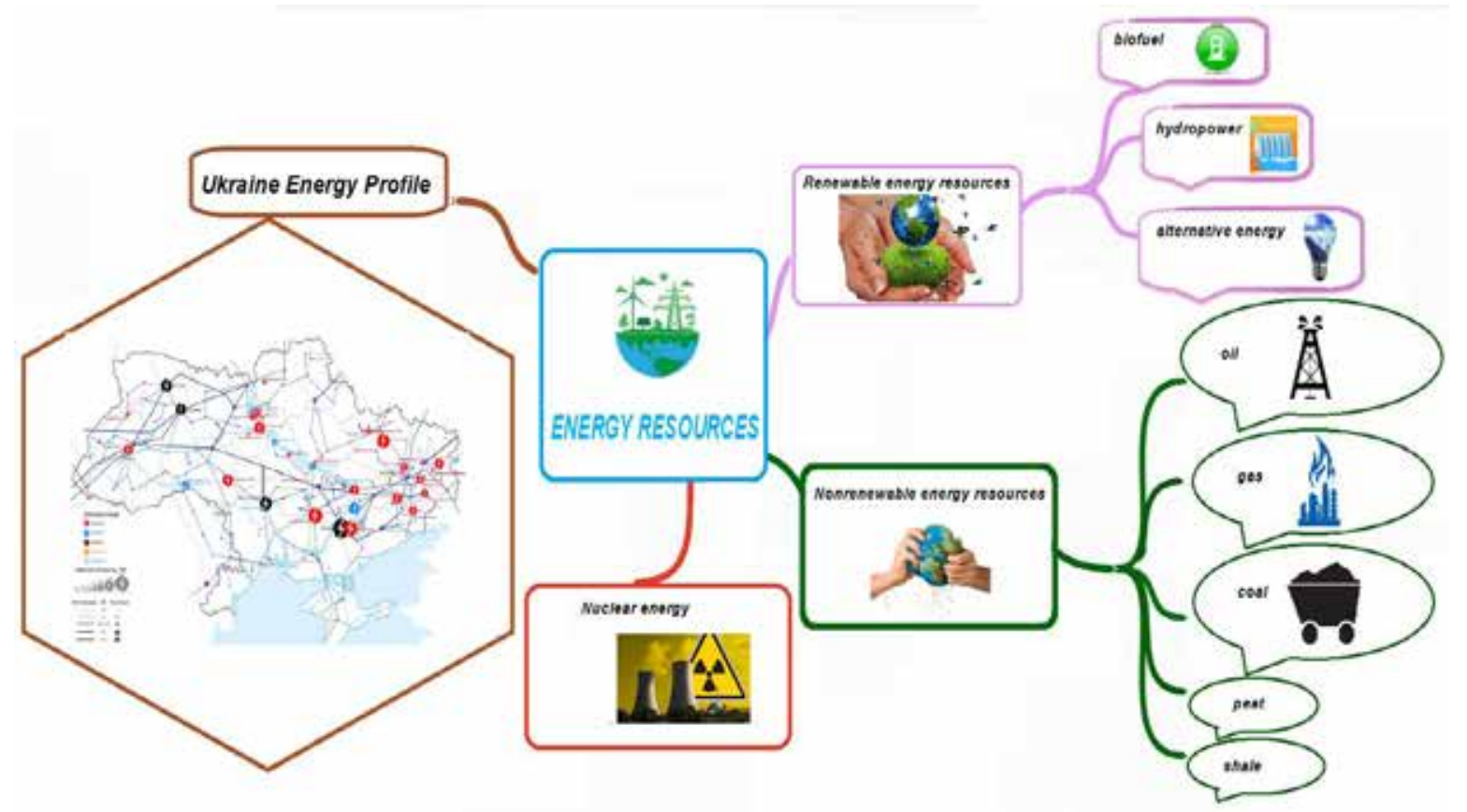

Рис. 1. Ментальна карта для монологічного висловлювання за темою «Energy Resources» 
навичок системного підходу до проблеми, наявності власної системи індивідуальних графічних і колірних символів. Необхідно пояснити, що головною метою завдання $\epsilon$ не створення ментальної карти, вона $є$ засобом розуміння, аналізу, фіксації, логічної організації інформації і кінцевим продуктом роботи.

Створювати ментальну карту студенти можуть як на папері від руки, так і за допомогою комп'ютерних програм. Для побудови графічних ментальних карт ми можемо рекомендувати зручні вебсервіси www.coggle.it, MindMeister. com, Bubbl. us, cacoo.com, комп'ютерні програми MindJet, Mind Manager Pro 6, Edraw Mind map, Visual Mind, XMind, FreeMind, iMindMap тощо. Можна використовувати також WikiMindMap - інтерфейс до Вікіпедії, що перетворює статтю Вікіпедії на ментальну карту, але така карта не буде повністю відповідати задачам навчання студентів іноземної мови.

Висновки та перспективи подальших досліджень. Проведене нами дослідження дало змогу зробити висновок, що використання ментальних карт мотивує студентів до оволодіння іноземною мовою як засобом спілкування, позбавляючи їх механічного процесу запам'ятовування інформації, дає змогу реалізувати широкий спектр можливостей загальнодидактичних методів нав- чання, розвиває в студентів мовну компетенцію, навички оперування мовними одиницями в комунікативних цілях, мовленнєву компетенцію, вміння планувати свою мовленнєву поведінку, розширює можливості організації інтерактивного навчання. Все це дає змогу викладачеві продуктивно використовувати навчальний час і отримувати високі результати в процесі іншомовної підготовки студентів.

Використовуючи ментальні карти на навчальному занятті з іноземної мови, варто враховувати такі методичні правила, як охоплення за допомогою карти всього навчального матеріалу, що стосується цієї теми, дотримання структурно-смислової єдності матеріалу, що вивчається, деталізація гілок основної ментальної карти за допомогою додаткових зображень, послідовне розгортання основної ментальної карти, оптимізація розмірів і кількості зображених елементів і зв'язків відповідно до можливості їх сприйняття студентами, підбиття підсумків на основі ментальної карти 3 деталізацією навчального завдання.

У подальших наукових дослідженнях плануємо продовжити порушену проблему щодо використання ментальних карт як інформаційно-комунікаційної технології самостійного і дистанційного навчання іноземної мови.

\section{Література}

1. Алексєєва О., Бутенко Л., Курліщук І., Швирка В. Використання інформаційно-комунікаційних технологій у процесі викладання курсу за вибором «Трендспоттинг та професійне майбутнє сучасного фахівця». Інформаційні технології $і$ засоби навчання. 2018. № 4 (72). С. 136-151.

2. Кобися А.П. Використання технологій майндмеппінгу у педагогічній діяльності. Сучасні інформаційні технології та інноваційні методики навчання у підготовиі фахівців: методологія, теорія, досвід, проблеми. 2015. № 41. С. 346-351.

3. Романовський О.Г., Гриньова В.М., Резван О.О. Ментальні карти як інноваційний спосіб організації інформації в навчальному процесі вищої школи. Інформаційні технології $і$ засоби навчання. 2018. № 2(64). C. 185-196.

4. Nesbit J., Adesope O. Learning with concept and knowledge maps: A meta-analysis. Review of Educational Research. 2006. Vol. 3(76). P. 413-448.

\section{References}

1. Aleksieieva, O., Butenko, L., Kurlishchuk, I., Shvyrka, V. (2018). Vykorystannia informatsiino-komunikatsiinykh tekhnolohii u protsesi vykladannia kursu za vyborom «Trendspottynh ta profesiine maibutnie suchasnoho fakhivtsia» [The use of information and communication technologies in the process of teaching "Trendspotting and modern specialist's professional future" elective course»]. Informatsiini tekhnolohii i zasoby navchannia, Vol. 4 (72). P. 136-151.

2. Kobysia, A.P. (2015). Vykorystannia tekhnolohii maindmeppinhu u pedahohichnii diialnosti [The use of technology of mind-mapping in pedagogical activity]. Suchasni informatsiini tekhnolohii ta innovatsiini metodyky navchannia u pidhotovtsi fakhivtsiv: metodolohiia, teoriia, dosvid, problemy, Vol. 41. P. 346-351.

3. Romanovskyi, O.H., Hrynova, V.M., Rezvan, O.O. (2018.) Mentalni karty yak innovatsiinyi sposib orhanizatsii informatsii $\mathrm{v}$ navchalnomu protsesi vyshchoi shkoly [Mental maps as an innovative way of the information organization within the higher education process]. Informatsiini tekhnolohii i zasoby navchannia, Vol. 2(64). P. 185-196.

4. Nesbit, J., Adesope, O. (2006) Learning with concept and knowledge maps: A meta-analysis. Review of Educational Research. Vol. 3(76). P. 413-448. 